\title{
FORUM
}

Submitted 07.31.2017. Approved 12.26.2017

Evaluated through a double-blind review process. Guest Scientific Editors: Marina Heck, Jeffrey Pilcher, Krishnendu Ray, and Eliane Brito

Original version

DOI: http://dx.doi.org/10.1590/So034-759020180304

\section{THE PRESENTATION OF THE CHEF IN EVERYDAY LIFE: SOCIALIZING CHEFS IN LIMA, PERU}

\author{
Apresentação do chef na vida cotidiana: Socialização dos chefs em Lima, Peru \\ Presentación del chef en la vida cotidiana: Socialización de chefs en Lima, Perú
}

\begin{abstract}
Over the past two decades, Peru has seen a dramatic expansion of restaurants and attention to Peruvian cuisine, a phenomenon known as the "gastronomy boom." Peruvian chefs have become national celebrities, their entrepreneurial and culinary efforts portrayed as a means of transforming Peru into a more prosperous nation. In this paper, based on sixteen months of ethnographic research in Lima, I examine socialization practices in two culinary schools to elucidate how culinary work is linked to person formation in Peru. I show that instructors encourage students to eschew business practices locally classified as vivo (dishonest and crafty) in order to become more orderly. They also instill in students the importance of having the ambition necessary to achieve international prominence. Together, these lessons promote a template for a new, ideal Peruvian citizen whose combination of extroversion and restraint exemplifies Peru's potential in the global economy.
\end{abstract}

KEYWORDS | Culinary education, socialization, entrepreneurship, Peru, gastronomy.

\section{RESUMO}

Durante as últimas duas décadas, o Peru tem assistido a uma dramática expansão de restaurantes $e$ atenção à sua gastronomia, um fenômeno conhecido como o "boom da gastronomia". Os chefes peruanos tornaram-se celebridades nacionais, e os seus esforços empresariais e culinários foram retratados como um meio de transformar o Peru em uma nação mais próspera. Neste artigo, com base em 16 meses de pesquisa etnográfica em Lima, examinei as práticas de socialização encontradas em duas escolas culinárias, para esclarecer como o trabalho culinário está ligado à formação de pessoas no Peru. Demonstro que os instrutores incentivam os estudantes a evitar práticas de negócios localmente classificadas como "vivo" (desonesto e astucioso) para se tornarem mais organizados. Também incutem nos alunos a importância de ter a ambição necessária para alcançar uma proeminência internacional. Em conjunto, essas lições promovem um modelo para um cidadão peruano jovem e saudável, cuja combinação de extroversão e restrição exemplifica o potencial do Peru na economia global.

PALAVRAS-CHAVE | Educação culinária, socialização, empreendedorismo, Peru, gastronomia.

\section{RESUMEN}

Durante las últimas dos décadas, Perú ha visto una drástica expansión de restaurantes y atención a su gastronomía, fenómeno conocido como el "boom de la gastronomía". Los chefs peruanos se han convertido en celebridades nacionales, sus esfuerzos emprendedores y culinarios se han retratado como medio de transformar Perú en una nación más próspera. En este estudio, basado en 16 meses de investigación etnográfica en Lima, examino prácticas de socialización en dos escuelas de gastronomía para aclarar cómo el trabajo culinario está relacionado con la formación de la persona en Perú. Muestro que los instructores alientan a los estudiantes a evitar prácticas de negocios localmente clasificadas como vivas (deshonestas y arteras) para ser más disciplinados. También infunden en los estudiantes la importancia de tener la ambición necesaria para alcanzar prominencia internacional. En conjunto, estas lecciones promueven un molde para un nuevo e ideal ciudadano peruano cuya combinación de extroversión y moderación ejemplifica el potencial de Perú en la economía global.

PALABRAS CLAVE I Educación culinaria, socialización, iniciativa empresarial, Perú, gastronomía.

\section{AMY LASATER-WILLE'} amy.lasaterwille@nyu.edu ORCID: 0000-0001-6904-8107 


\section{INTRODUCTION}

Carlos divided his students into two groups. Pulling ourselves off the dusty tile floor, we shuffled to either side of the classroom and formed two lines: five women on one side facing four men on the other. Carlos waited in the middle. When we had organized ourselves properly, he told us the assignment: one by one, each student from the male side of the room would cross and pretend to seduce the female student of his choice. The object was to project power and confidence; if a student seemed weak, he would have to do it again. "Do you know who Sean Connery is?" Carlos asked in Spanish by way of explanation. "Isn't he a hunk? He's old, but he can get whatever he wants.”

He stood back and motioned to Esteban (a pseudonym), a tiny eighteen-year-old who was standing at the end of the line directly across from me. Esteban walked toward Maripas at the other end of my line, putting one foot in front of the other and maintaining eye contact, purposeful but shy. "Not confident enough!" Carlos called out, then demonstrated how one crosses a room by striding towards a girl named Wendy, who giggled when he stopped just short of touching her. "Again!" he said. Esteban tried once more, faster and with a straighter posture.

One by one, my classmates practiced their seduction walks, first the men and then the women. Round-faced Leomar was told to be more galán (powerful like a leading man); Victor, at thirty the oldest student and unofficial leader of the class, found himself praised for his ramrod posture and confident gait. "Remember," said Carlos once everyone had finished, "You should always be confident. If you are, then no one can say anything bad about you." He released us into the humid afternoon, each of us brushing off our baggy checkered pants and filing past the empty classrooms toward Cenfotur's main exit.

Carlos was teaching what amounted to an acting class, but Cenfotur is not an arts school; it is a state-funded tourism institute in a coastal neighborhood of Lima, the capital of Peru. My classmates were starting their first of four semesters in the school's culinary degree program. Carlos's class, Taller de Desinhibición (which translates roughly as "workshop for lack of inhibition") was a required weekly course. When, as an anthropologist participating in classes at Cenfotur, I mentioned to my classmates that I was surprised they had to take an acting class, I discovered that nearly all of them thought it natural. They assumed that an education in self-presentation should naturally be embedded in culinary training. Likewise, culinary school administrators tended to explain their missions as "formando gente" or "creando personas," forming or creating people as opposed to training professionals or imparting specific skills.
Indeed, while Peruvian culinary schools do teach students culinary skills, the traits that students and teachers agreed were vital for a chef often had little to do with to cooking itself; instead, they largely convey elements of character, as well as ways of approaching the world and interacting with others. In this article, I argue that these characteristics have become integral to the cultivation of the Peruvian chef because they create a workforce with a distinctive blend of extroversion and restraint, a combination of traits that instructors laud for its appropriateness for interacting with tourists and international consumers. However, the process of creating these workers has implications beyond the mere cultivation of a specific vocational workforce. As culinary schools work to develop particular kinds of restaurant workers, they also see themselves as developing national and global citizens, ideal members of society whose adherence to international culinary norms serves as evidence that Peru's working class can be reformed. As a result, the inculcation of the consummate chef's qualities in Lima's culinary students alleviates anxieties about Peru's suitability for the global marketplace. It also aligns with a growing global tendency to see chefs as activists and reformers, a movement that portrays character development in culinary schools as having the potential not only to improve individual prospects, but also Peru's standing in the world.

\section{METHODS AND BACKGROUND: THE GASTRONOMY BOOM AS AN ANTHROPOLOGICAL FIELD SITE}

On September 13, 2011, an international group of celebrity chefs calling themselves the $\mathrm{G} g$ released a statement outlining chefs' social obligations and trumpeting their capacity to change the world. Called the Lima Declaration, this "open letter to the chefs of tomorrow" was drafted during the 2011 session of Mistura, Peru's annual gastronomy festival. It contains seven points divided into four sections, outlining the culinary world's responsibility to improve nature, society, the transmission of knowledge, and artistic expression (Bianchi, 2011).

As this declaration made its way into newspapers and blogs worldwide, the response was largely incredulous. The Guardian's Word of Mouth blog ran an opinion piece by critic Jay Rayner titled "Chefs' manifesto: Reality check, please" that diagnosed the chefs with "having made the terrible mistake of thinking anybody really gives a damn what they think" (Rayner, 2011). Even members of the listserv for the Association for the Study of Food and Society approached the news about the transformative power 
of chefs with a skeptical eye. In Peru, however, the response to the Lima Declaration was celebratory. El Comercio viewed the G9 conference as a sign of progress for Lima's culinary scene (Pastor, 2011). Meanwhile, the latter portion of the comments section of Rayner's blog became a forum for Peruvians to explain the Lima Declaration in the context of their country. "To understand why this group of chefs decided to sign a manifesto that many of you find cheese [sic] and over the top, you will only understand after you study what has happened in Peru in the last 10 years," one commenter summarized. "I invite you to do a report of the work that Gaston [Acurio, a celebrity chef] has been doing in Peru and you surely will be inspired enough to sign a Manifesto [sic] like that."

As these reactions might indicate, while the idea of a chef as a political figure might seem ludicrous outside of Peru, for many people in Lima, the portrayal of chefs as figures of development and salvation has become almost a matter of common sense. Indeed, for the people I knew in Lima's culinary schools and restaurants, cuisine was a natural focal point for discussions about the future of society. Part of this confidence in the culinary industries is related to specific historical and economic circumstances. In 1992, the year that many of my classmates were born, Peru was just emerging from more than a decade of terrorism and economic collapse; by the 2000 , a series of neoliberal economic policies and the rejuvenation of business had made Peru's economy one of the fastest growing in Latin America. Some of Peru's most successful businesses profit from the extraction of natural resources; however, many others are linked to Peru's food and cuisine, ranging from the export of asparagus, quinoa, and paprika to the reinvigoration of tourism. The emergence of these food-related businesses has taken place in tandem with the growth of food-related travel, media, and celebrity worldwide, making a focus on Peruvian cuisine part of a broader growth in the culinary industries enabled by the media and tourism (Rousseau, 2012; Ruhlman, 2006). Today Peru's "gastronomy boom" is evident in the Peruvian restaurant chains that have spread across South America and Europe, as well as in the estimated $3 \%$ of Peru's gross domestic product (GDP) that is attributed to restaurants within the country (Economist, 2014). In 2017, Peru was home to two of the top 20 restaurants in the world (William Reed Business Media, 2017). In this environment, cooking is an accessible profession that has the potential to reap vast rewards, and thousands of young people from around the country have enrolled in culinary schools to emulate the chefs who have become some of their most cherished celebrities.

It is not only the potential for profit that has driven young Peruvians to enroll in culinary schools and open restaurants, though; it is also the widely disseminated message that food is integral to the expression of Peruvians' individual personal identities and their shared heritage as Peruvians. This message is similar to the identification of food with heritage that occurs in many locations around the world (Counihan, 2004; Fajans, 2012; Sutton, 2014), but Peruvians see the form of their gastronomy boom as quintessentially their own. Many people told me that this emphasis on food had to some extent always been present in Peru; they told me that Peruvians naturally love to eat, that they have especially good taste, and that they have always been good cooks. At the same time, they speculated that the gastronomy boom has emerged at this particular moment because Peruvians need to remember that there is something they all do well. Perpetual losers in war and soccer, cuisine is a sphere in which Peruvians of all socioeconomic and ethnic backgrounds are now winning on a global scale.

The overt message of this common trope - that Peru's gastronomy boom will provide the opportunities and ethos necessary to create a more prosperous and inclusive society - is an easy one to approach with cynicism; many Peruvians I met, rich and poor alike, were skeptical of the chefs and gastronomy society officials who make these claims. Social scientists analyzing these campaigns have also rightly pointed out that the gastronomy boom's brand of "inclusion" actually excludes the contributions of many groups of Peruvians, often the same groups who have historically been barred from elite spaces (Alcalde, 2009; García, 2013). However, limiting an analysis of the gastronomy boom to its rhetorical inaccuracies runs the risk of obscuring the very real effects that the boom has had on many people's lives. Instead, the "gastronomy boom" should be seen anthropologically, not just as a set of claims about inclusion and diversity, but also as a series of social and political maneuvers that have rearranged a landscape of economic opportunities, created new hierarchies and credentialing procedures, and rewarded new kinds of comportment, sociability, and self-perception.

Lima's culinary schools - many of which did not exist twenty years ago, or if they did, it was in a much-reduced form - are ideal locations to study these changes because they are the sites where many of these new beliefs and behaviors are instantiated. To this end, I conducted 16 months of ethnographic research in Lima from August 2011 to December 2012. During this time, my primary methodology was participant observation in two mid-priced culinary schools: Cenfotur and a school I am calling LaCucina, which enrolls a large number of rural-to-urban migrants and their children. These students often came from humble means, but every day they heard from their teachers that they had the potential to become as influential as celebrity chefs if they applied 
themselves appropriately. As I will show, in both schools, this means that students learn to embody a calculated mixture of international norms and Peruvian traits. The process of learning to create these personas prepares students to represent Peru (and sell Peruvian food) to the world. It has also served as a means by which instructors have created a new kind of model Peruvian citizen, transforming a potentially troublesome population of poor migrants into creative, capitalist workers whose characteristic trait is entrepreneurialism.

In teaching their students the behavior of proper employees, Peruvian culinary instructors are in good company worldwide. Social scientists have long noted the connection between the socialization of personal characteristics and the formation of capitalist workers, from E.P. Thompson's seminal work on the socialization of dispositions among the English working class (1964) to more recent work on the flexibility valued in presentday employees, who are expected to continuously adapt to the demands of rapidly changing work conditions (Comaroff \& Comaroff, 2001; Ong, 1999). Notably, anthropologists have described workers of the past several decades as thinking of themselves through a perspective of "neoliberal agency," a sense that their identities, abilities, and even cultures are marketable "assets that must be continuously invested in, nurtured, managed, and developed" (Martin, 2000, p. 582; Gershon, 2011). Seen from this angle, formal education is a means to a very capitalist mode of self-improvement; effective neoliberal workers see themselves as gaining credentials, relationships, and skills from schooling that can be reinvested into the self like a business.

Vocational education in Peru, much of it private, draws explicitly on this view of schools as a form of investment. Rural children move to cities specifically to "improve [themselves]" through education and implicitly to become morally superior through schooling (Leinaweaver, 2008). Families across the country spend large portions of their income on private education - to a degree that surprises outside observers - because they believe in a direct tie between education and better jobs (World Bank, 1999). Like many vocational schools in Lima, LaCucina and Cenfotur have benefitted from this ideology. Both schools are twoyear institutes that offer state-recognized cooking credentials; as such, they are widely regarded as offering good value, providing students with knowledge and advantages in exchange for a relatively hefty tuition (about 1,000 soles or $\$ 380$ per month). They attract students from across Peru's socioeconomic spectrum, but - in part because Lima's richest students choose to study cooking at universities or abroad - these schools' student bodies are overwhelmingly made up of the country's middle class and students who are migrants or the children of migrants.
Many scholars who study Peru worry that the education offered in places like Cenfotur and LaCucina is a form of "racism in disguise" in the sense that it encourages students to adopt traits associated with whiteness in order to progress (Leinaweaver, 2008). These warnings are especially poignant as scholars worldwide have noted that "progress" itself may be ephemeral in the sense that formal education tends to reinforce class stratification rather than enable upward mobility. Key to these critiques is the insight that education reproduces and legitimizes the dominance of some cultural signifiers over others. Bourdieu and Passeron (1977) argue that education is a process of social exclusion because it enables the transmission of cultural capital within classes; meanwhile, Paul Willis notes that lower-class students participate in their own economic subjugation by opting into working-class jobs in what they perceive to be a fulfilling act of rebellion against conformity (1977).

As I will show, concerns surrounding the role of Peruvian education in reproducing existing hierarchies are not unfounded. Lima's culinary students are indeed encouraged to think of themselves as collections of individual culinary talents that can be marketed worldwide; they are distinguished from each other through grades, internships, and eventual work placements that reinforce the belief that some behaviors and tastes are superior to others. Yet strikingly, the characteristics into which Peruvian students are socialized are also part of a specifically Peruvian milieu, one that reflects not just the individual's place in the market but also the relationship between capitalist systems and Peru as a country more broadly - a context in which Peru as a whole was until recently seen as underperforming. In contrast to many of the vocational schools profiled in anthropological literature (cf. Woronov, 2015), the individual students at Cenfotur and LaCucina are not seen as "failures" or automatically of lower ability or lower class than students in academic tracks. Instead, the overwhelming sentiment in these schools - and, indeed, in Lima as a whole - is that Peru must work as a country to rise above its class position. With the individual student framed as a kind of metonym for Peru's progress, the entrepreneurship that my classmates learned to exemplify bore the traces not only of neoliberal agency, but also of Peru's specific racial ideologies, self-consciously promoting the notion that individual success is tantamount to national improvement.

\section{Vivo citizens, Vivo nation}

During my fieldwork in Lima, nearly every culinary school administrator I interviewed told me that the objective of cooking 
school was to form students into good people (buenas personas), whom they described generically as "ethical" or "responsible." Implicit in this characterization was the looming vision of a society that would prevent students from being good people if left to their own devices; when administrators referred to creating "buenas personas" they emphasized the fact that they were molding students who were not already good when they arrived. One administrator told me that many people came to Cenfotur with an attitude that would permit unethical behavior, and it was his job to train them to be different. With training, the students could become honest and attentive to order and cleanliness. Without it, students would likely become cooks who stole from their employers, sold expired or badly handled food, or told customers that the restaurant was serving a more expensive fish like lenguado (sole) when instead it was selling a different, cheaper fish that looked similar.

When instructors told me about this type of person, they often used the word vivo, which literally means "alive" but in Peru refers to being crafty or clever, capable of flouting official rules in order to achieve personal gain. While not overtly racialized, the term references a long history of ambivalence toward the presence of rural or indigenous people in Peruvian cities. Anyone in Peru can be vivo, but it refers to a type of craftiness that skirts official norms and as such often implies a contrast with a way of life that is more appropriate and implicitly European. In Lima, the association between indigenous traits and vivo behavior is all the more powerful because it links the supposed disorder of indigenous migrants to the perceived decline of the city over the past fifty years. For centuries after the Spanish conquest, Lima was depicted as a white enclave, but since the mid-twentieth century, an "overflowing” popular sector has moved from the provinces to the capital. The city grew from 1.5 million people in 1950 to eight million by the year 2000 (Matos Mar, 1984). In the absence of adequate public services in the latter part of the twentieth century, these migrants were famous for behavior that would be categorized as vivo, starting informal businesses and illegally occupying land that would eventually become Lima's vast shantytowns. Food production holds a special place in these racialized imaginaries. Indigenous and mestizo (of mixed heritage) vendors have been accused of falsifying their wares since colonial times (de la Cadena, 2000; Weismantel, 2001), and migrant market workers were often the central antagonists of stories people told me about dangerous, unhygienic, and vivo behavior.

In this context, culinary schools' explicit goal of transforming their migrant students into good people seems to be a thinly veiled project of civilizing Peru's indigenous youth. It is true that chefs' qualities like hygiene, integrity, and honesty - some of the ideal personality traits that students at Cenfotur and LaCucina are told to exemplify - are all characteristics that a vivo person stereotypically lacks. Some of the schools' methods of instilling these traits, such as lessons in hand washing, echo centuries of Latin American colonial and republican efforts to reform indigenous citizens and mestizo-dominated spaces like marketplaces (Aguilar-Rodríguez, 2007; Pilcher, 1998).

On the global scale in which the gastronomy boom operates, however, the term vivo has increasingly become a signifier of Peruvianness rather than of mere indigeneity. Today, even Peruvians who might describe themselves as being part of the old, pre-migrant Lima find themselves looking to indigenous characteristics to define "Peruvianness." Many referred to themselves as engaging in vivo behavior and identified it to me as being specifically Peruvian -even patriotic. This identification partly exists because the gastronomy boom relies on marketing the indigeneity of its ingredients and cooks as "traditional," revalorizing features that can be advertised as explicitly Peruvian. It is also a natural extension of the binary logic that governs Peru's racial ideologies: European-descended Peruvians are more European than their indigenous neighbors, but in a global context, they are less European than Europeans themselves. It makes sense to market oneself as vivo because it seems both differentiated and authentic.

As a result of the blurred lines between indigeneity and Peruvianness on the global stage, one prominent anxiety in present-day Lima is the worry of how to harness or celebrate Peru's vivo elements without descending into a mode of interacting with the world that is too reminiscent of Lima's internal migrants. For the culinary instructors I knew in Lima, navigating this compromise was vitally important, not just existentially, but also economically. Peruvian food would never become world-famous if it were perceived as incompatible with the regulations of the U.S. or Europe, but it would never be valuable if it were not also quintessentially Peruvian.

In both of the schools I attended, the solution to this problem was simultaneously behavioral and culinary, the cultivation of a new category that was vivo but also refined. This tactic was reflected in the lists of ideal personality traits that students and instructors regularly generated during the first days of school. Oft-mentioned chefs' qualities like hygiene, integrity, and honesty are all characteristics that a vivo person must learn. Crucially, however, the same lists also include elements like leadership and confidence, characteristics that are as much properties of the vivo persona as they are of chefs. 
Transforming culinary students into good people was thus a matter of combining these disparate sets of characteristics, tempering the vivo personality with well-mannered habits and practices.

Alicia, an administrator at LaCucina, provided a typical explanation of how the gastronomy boom was beholden to Peru's uniquely vivo traits and to the educational processes that translated them into marketable skills. During our first meeting, she told me that one of the gastronomy boom's chief benefits was that it allowed a wide variety of people to participate in the perks of culinary entrepreneurship. With a bit of ingenuity and talent, anyone could open a restaurant or culinary business with very little overhead. For Alicia, the characteristics that made this kind of success possible were specifically Peruvian. "El peruano es ingenio; el peruano es creativo," she told me during our first meeting ("Peruvians are ingenious; Peruvians are creative"). Although the adjectives she used to describe this uniquely Peruvian trait did not include the word vivo, the advantages of being ingenious or creative that she mentioned were clearly linked with the informal structures in which vivo people have learned to achieve their goals. One of the success stories she cited was about a man who sells food out of his car on the weekend to supplement his day job at a hospital; another was about a woman who had noticed a new construction site near her house and, divining that this would be an excellent market for her food, began selling sandwiches to workers. "Or you could just open your window and put out a table and chairs," Alicia said, concluding that one benefit of this system was that success or failure was entirely up to the person who had created the business.

Alicia was far from the only person I heard remark upon the positive, entrepreneurial advances that Peru's pervasive informal economy had made possible. Yet while this attitude toward informality made sense in the context of promoting a sanitized version of vivo characteristics, it presented a conflict in culinary school lessons. Nearly every teacher I talked to mentioned the need for the gastronomy boom to promote the formalization of businesses, the necessity of encouraging practices like paying taxes and workers fairly, or of not cutting corners that would sicken the populace. When I asked Alicia how she could extoll the benefits of informality while the gastronomy boom focused so strongly on formalization, she explained that worries about informality were largely directed toward large businesses that did not pay taxes. In contrast, the microempresas (small, entrepreneurial businesses) were "basically good” but needed to work on aspects of their businesses that were still lacking, such as hygiene.
Alicia's answer is a revealing example of how the gastronomy boom retains elements of a crafty brand of entrepreneurship while also acquiring a veneer of respectability. For Alicia and other administrators, the formalization that culinary entrepreneurs must undergo is not so much a denial of the Peruvian spirit of being vivo, but rather the ability to demonstrate other characteristics that allow vivo-ness to become integrated into commerce. In other words, a person might be vivo but must also be hygienic, educated, and ethical in order to represent Peru at home and abroad. It is partly this compromise that makes the Peruvian gastronomy boom seem so transformative in its home country. As entrepreneurial endeavors that acknowledge the peculiarities and potentially corrupt characteristics of Peruvian informality, businesses that exist within the framework of the gastronomy boom also demonstrate Peru's ability to integrate itself into global markets after a disastrous period of near collapse.

In order to signal this compromise between formality and vivo characteristics, cooks and restaurant owners must learn to embody a specific combination of skills and personality traits. In the rest of this article, I will describe how this very specific combination of Euro-American standards and Peruvian character has become part of culinary students' social and embodied practices, both via explicit instruction and in their schools' disciplinary practices. As I will show, while the schools deliberately socialize particular habits and outlooks in their students, the particular combination of these habits - the characteristic persona that allows students to embody something that is Peruvian and international (usually Euro-American) at the same time - is less of a model of capitalist citizenship in general than it is of Peruvian capitalism in particular. The result of this socialization process is an image of Peruvian capitalism in which vivo behavior is transformed via daily interactions and channeled into the drive to promote Peruvianness abroad.

\section{Order and research in the classroom}

When Alicia told me that the informal vendors of the gastronomy boom were "basically good" but needed to learn hygiene and education, she was articulating a view in which a person's vivo behavior and informality could be offset by acquired skills and made acceptable for tourists and international consumers. This attitude, widely shared among educators, was often the basis for explaining why culinary students needed to learn how to conduct themselves in orderly ways. On my first day at Cenfotur, for instance, one of the instructors told me that training cooks was like training soldiers in an army. By this he meant that he taught students to 
respect the strict hierarchies of the kitchen, but also that it was important to cultivate the disciplined, orderly habits of a group that worked together toward a shared goal. In theory, every aspect of a typical day in Lima's culinary schools was inflected with this commitment to discipline, though it was not always expressed as a direct analogue to military life. At both of the schools I attended, each day began with a student displaying his or her official ID and changing into a uniform; as it progressed, students typically found themselves in work environments in which they took on specific, defined roles like chopping, cooking, plating and cleaning.

Within these broad routines, instructors at both schools also encouraged the efficient and orderly execution of particular tasks. In both schools, the concept of mise en place was one of the first procedures that instructors taught; they explained that the French term meant "everything in its place" (todo en su lugar) and that it usually referred to the cutting and portioning of ingredients in advance of cooking, a process that saved time and allowed many kinds of dishes to be cooked right before serving. They also emphasized that mise en place referred not just to preparing the ingredients, but also to organizing oneself so as not to waste time. It was partly a mindset, the mental preparation that all cooks undertook so as to predict the most efficient preparation of their part of a dish. Accordingly, the correct sequencing of tasks was as much a manifestation of order as was the organization of space. When instructors demonstrated how to prepare a dish in a cooking class, they often narrated the rationale behind the order in which they were completing the steps, asking students which component of a dish would take the longest to prepare and thus which aspect they should begin first.

Finally, the orderliness that these schools taught in the kitchen was connected not only to the physical environment, but also to an individual's attention and attitude. Safety protocols were an especially obvious focus for this lesson as instructors taught students to be aware of flames, of the settings on pressure cookers, and the locations of fire extinguishers. Instructors also carefully reinforced attention to the food itself. They were usually lenient about mistakes that were made due to misunderstandings of recipes or techniques but were unforgiving of students whose errors came from neglecting to watch a searing piece of meat, ignoring a cheese-covered dish in a broiler, or forgetting to add a key ingredient.

Despite the ubiquity of these manifestations of order, no instructor spoke of an attention to organization or the capacity for restraint as traits that were naturally well-suited to Peruvians. Instead they described order as though it were a visitor from abroad, an anomaly that might choose to return to its homeland if not treated properly. Culinary instructors who had been to Europe lectured students on the fact that Spanish and French restaurants were far more organized than anything they had seen in Peru. Almost all descriptions of mise en place emphasized the procedure's French origins, while discussions about the need for methodical library research or experimentation usually began with the example of Ferran Adrià, a Spaniard. The United States was also a common model for organization; two of the bartending teachers at LaCucina had been employed at a major American casual dining chain in Lima and regaled their students with tricks that American consultants from the chain's corporate headquarters had taught to their employees.

While the instructors took as a given that none of the students could be expected to spontaneously adopt an orderly attitude, they emphasized that these forms of discipline were a necessary check on the attitudes that Peruvians already believed they had. This necessity came not just from the goal of improving the Peruvian populace, but also from pragmatic concerns about attracting tourists and sending culinary students to restaurants around the world. Peru's cooks might be creating food for international consumption, but - in keeping with the perspective of "neoliberal agency" within which the schools imagined themselves to operate - in many ways instructors saw cooks themselves as products that needed to be molded to suit foreign tastes while differentiating themselves from competitors. To this end, Peru's culinary schools emphasize the need to combine the orderliness expected in the international workforce with the traits that separate Peruvian cooks from those of other nationalities. Chief among them is a modified version of vivo behavior.

\section{Ganas}

While order in all of its manifestations was something that culinary students and instructors understood to be unquestionably foreign, traits like ambition and leadership were understood to be native to Peru. They were not qualities that every Peruvian necessarily had, though, and students could be evaluated and compared according to the quantity of ambition they displayed at any given moment. I became especially aware of this tendency when I was invited to observe the morning classes at the Instituto Pachacutec, an elite school that enrolls migrant students on full scholarship and trains them to work at some of the most famous restaurants in the country. I spoke with a chef instructor as he watched over a group of students in their final semester. "I like these students better than the students from other schools," he said as we 
watched the students crack open crab shells. "I teach at Cordon [the Lima branch of Paris's Cordon Bleu school] too, and I prefer to hire the students here. Cordon has better facilities, but the students here have more ambition."

The word I am translating as "ambition" here is the Spanish noun ganas, which is related to the verb ganar ("to win" or "to earn") and refers to a person's hunger or desire. A person who has ganas is ambitious or even scrappy, while a person without ganas is apathetic, lackadaisical, or disinterested. Unlike order, my interlocutors viewed ambition as something one comes by naturally, not something that can be acquired by immersing oneself in an appropriately organized environment or dressing according to a code. They believe that ambition can be harnessed and to some extent augmented. As a result, instructors tended to frame obstacles to student success as the product of merely misrecognizing or forgetting ambition. One bartending teacher ended a lecture with a quote from Victor Hugo: “A nadie le faltan fuerzas; lo que a muchísimos les falta es voluntad" (often translated in English as "People do not lack strength; they lack will”). Another teacher critiqued a series of poor student presentations with the admonition, "It's not a matter of ability, it's interest" ("No es cuestión de capacidad, es de interés").

While it was necessary for students in this environment to know privately that they had the requisite drive to succeed, just being motivated was not enough. They also had to know how to properly display their ambition so that their instructors would recognize and reward it. At both LaCucina and Cenfotur, instructors were aware that such displays were in part cultivated performances, and they required students to take classes in which they learned how to play the role of a dedicated culinary student. Cenfotur's Taller de Desinhibición was one example of a class that taught students the ways that a passionate, driven chef should look and act. When Carlos the actor had his students pretend to seduce each other, he stressed that the most important expression of personality that a student could cultivate was confidence. His description of Sean Connery - "He's old, but he can get whatever he wants" - describes the ideal state of someone with ganas: the ability to recognize one's desires and go after them with assurance. Furthermore, Carlos's specific advice to the students about how to embody confidence - such as his instruction that a person must try to look gallant, to use wiles or appearance, to cross a room with purpose, and to ignore those who might criticize or doubt them - suggests that confidence is something performed or displayed as much as it is felt.

In this sense, Carlos and other instructors' views on behavior echo the work of Erving Goffman, whose book The Presentation of Self in Everyday Life pays similar attention to the impressions that might result from a person's performance and mannerisms (Goffman, 1959). However, unlike Goffman who imagined a private “backstage" for the self, Peru's culinary performances have been predicated in part on the manipulation of the private self. For one thing, instructors have worked to manipulate beliefs under the assumption that appropriate dispositions lead to good behaviors. Furthermore, these instructors also believe that merely behaving properly will affect a student's attitude (see Mahmood, 2005 for a discussion of a similar theory about the relationship between disposition and belief). To this end, Carlos's class was not just about acting, but also contained exercises meant to generate a feeling of self-confidence that promotes displays, like an appropriately seductive walk across a room. The result represents an ambition that is both recognizably on display and plausibly a reflection of an authentic, interior self.

\section{A different kind of ambition}

The insistence that a student demonstrate ambition and confidence may at first seem tantamount to instructing students to be vivo. It is certainly true that a vivo person has ganas. Yet in teaching their students to express their ambitions, culinary instructors also emphasize the differences between vivo behavior and the kind of ambition acceptable in the culinary world. Crucially, the difference between being vivo and an ambitious cook is the type of social relationship that the two positions entail. A vivo person is someone whose ambition takes precedence over the welfare and aspirations of others. Being able to cut in line or swindle a customer are vivo skills; the desired result is not necessarily advancement, but rather dominance in relation to others. In culinary school these are exactly the kinds of behaviors that instructors described as unacceptable. In their place, they encourage students to practice a kind of ambition that is not a zero sum game, but rather a desire for a kind of success that lifts others up with them. Claudio, one of the teachers at Cenfotur, explained the difference between these two forms of ambition by telling the class a joke (which I am paraphrasing here):

One day a man went to the market to buy crabs. He found a fisherman with two cages, one of which was labeled "Peruvian crabs," the other "German crabs." Then he noticed a difference between the two cages. "Why is it that the cage for the German crabs has a lock and the Peruvian one doesn't?" he asked. 
"Oh, that's simple," said the fisherman. "When a German crab tries to escape, he pulls the other crabs up with him. If one gets out you lose them all. When a Peruvian crab tries to escape, the other crabs pull him back down so that he can never get out. The Peruvian crabs don't need a lock." (See Wilson, 1973 for a similar anecdote told in the Caribbean context)

Claudio told this joke in the context of an impromptu lecture in which he was explaining to students that they needed to shed the tendency to measure their own value through comparisons to their peers. The crucial lesson of the Peruvian crabs is that the wrong kind of ambition is harmful to everyone, even if it momentarily assuages an individual's worry that he or she is not as successful as others. In attributing this misunderstanding of advancement to the entire nation, Claudio was offering not only an explanation of Peruvians' pessimistic perceptions of their own county, but also an acknowledgement that his students' self-sabotaging interpretations of the value of ambition would be difficult to change.

It is perhaps for this reason that Cenfotur's approach to transforming vivo ambitions works in part by transforming students' assessments of their own emotional states and characteristics. Instructors encourage students to support each other by working as a team, and Carlos's exercises often centered on having students recognize each other's altruistic tendencies rather than pure ambition. Culinary instructors in both schools have also created a conceptual difference between vivo behavior and the appropriate manifestation of ganas by stressing the fact that a culinary student should have very specific, socially conscious goals. Instructors emphasize that their students are future leaders who might one day have a responsibility toward those whom they would lead. This framing of ambition encourages students to have loftier goals than they might otherwise have. For many people I spoke with, knowing one is capable of working in a restaurant kitchen is not a sufficient goal for a future leader; students also felt they should have the ganas to work until they reach the assumed endpoints of the Peruvian culinary career: becoming a chef, working internationally, or opening a restaurant. Further, students felt pressure to become socially conscious versions of these endpoints. It was not necessary for every chef to be a philanthropist, but in this worldview it was not permitted for a chef to take advantage of others in the way that a stereotypically vivo person might.

In this context, in which education is explicitly framed as the road to national improvement, analyses of scholars like
Paul Willis are both confirmed and complicated. Willis warned that the illusion of upward mobility through education is part of what makes class structures endure, noting, "A few can make it. The class can never follow. It is through a good number trying, however, that the class structure is legitimated" (Willis, 1977, p. 128). Peru's culinary schools exemplify this analysis to some extent, as lower class students often have greater difficulty performing the signs of orderliness and education than their peers. However, with a direct focus on the social body "making it" rather than the individual alone, Peru's culinary scene also contains examples of hiring practices that belie a strict focus on credentials or status. One notable example is the tendency among restaurants to hire very talented self-taught cooks in addition to formally educated culinary school alumni (a fact that the culinary schools tend to downplay or deny). When I asked chefs about why they hire both types of cooks, they articulated it as a need to find a balance in the kitchen, typically between the more vivo cooks "off the street" and the more restrained culinary graduates. In other words, the social unit as a whole needs to acquire the balance of skills and dispositions that would ensure success in the marketplace - which means that individual adherence to the model of the chef espoused in Cenfotur or LaCucina is not always necessary for success.

\section{CONCLUSIONS}

As the pervasive emphasis on behavior in culinary classrooms might indicate, finding the appropriate place for vivo behavior is a central preoccupation of Peru's culinary schools. Like many limeños, students and instructors at LaCucina and Cenfotur see some aspects of vivo behavior as beneficial to future chefs; in their daily interactions in the classroom, they determine the extent to which ambition must be accompanied by organizational skills, order, and teamwork. In this way, the inculcation of behavioral norms at schools like LaCucina and Cenfotur has transformed vivo behavior into an interaction that is used for entirely different ends than the selfish or antagonistic goals that vivo entrepreneurs are usually assumed to embody. The gastronomy boom's emphasis on leadership rather than personal gain allows the expression of vivo ambitions to focus on the social good that a student (and later a cook or a chef) can accomplish, rather than the extent to which he or she has advanced beyond others. This shift in the meaning of what it is to be vivo is one major reason that a chef's potential effects on society are so readily accepted in Peru. Where the rest of the world sees the G9's Lima Declaration as a profession's 
collective delusion of grandeur, Lima sees a profession in which harnessing a quintessentially Peruvian trait might lead to social improvement.

Even more significantly, however, the gastronomy boom reframes the scope of the competition in which a person might be ambitious. Focusing on the global market as the arena in which Peruvian chefs must make an impression, this boom creates the sense that Peru as a whole must be crafty in order to assume an advantageous place in the world. In Claudio's joke, the humor of comparing the Peruvian and German crabs comes from thinking of the two cages as isolated and imprisoning structures. Yet if Peru's culinary students imagine themselves as crabs escaping from a cage and pulling the other crabs with them, it is partly because they know that there is a bigger cage beyond the one in which they have been living. And in the bigger cage, in which they would encounter the crabs from all of the other nations, the Peruvian crabs - with a sensibility that combines both order and ambition - just might be the best.

\section{ACKNOWLEDGEMENTS}

Portions of the research on which this article is based were funded by the National Science Foundation (Award \#BCS 1155923), New York University's Annette B. Weiner Graduate Fellowship in Cultural Anthropology, and the ZEIT-Stiftung Bucerius PhD Scholarship in Migration Studies. I also thank the Pontificia Universidad Católica del Perú, where I was an affiliated researcher during my fieldwork. I particularly thank Alex Huerta-Mercado, whose advice during my early fieldwork ultimately helped shape the argument in this article. Early versions of portions of this paper were presented at the 2013 Bucerius Student Conference and the 2013 American Anthropological Association Annual Meeting; I thank my fellow participants for their feedback. Finally, I am grateful to the students and teachers at Cenfotur and the school I am calling LaCucina in Lima for their hospitality and insight.

\section{REFERENCES}

Aguilar-Rodríguez, S. (2007). Cooking modernity: Nutrition policies, class, and gender in 1940 s and 1950 s Mexico City. Americas, 64(2), 177-205.
Alcalde, M. C. (2009). Between Incas and Indians: Inca Kola and the construction of a Peruvian-global modernity. Journal of Consumer Culture, 9(1), 31-54. doi:10.1177/1469540508099700

Bianchi, L. (2011, Sep. 13). Lima declaration - Open letter to the chefs of tomorrow [Blog post]. Retrieved from http://www.theworlds5obest.com/ blog/Events/-lima-declaration-open-letter-to-the-chefs-of-tomorrow.html

Bourdieu, P., \& Passeron, J. (1977). Reproduction in education, society, and culture. Beverly Hills, CA: Sage.

Comaroff, J., \& Comaroff, J. L. (2001). Millennial capitalism and the culture of neoliberalism. Durham, NC: Duke University Press.

Counihan, C. M. (2004). Around the Tuscan table: Food, family, and gender in twentieth century Florence. New York, NY: Routledge.

De la Cadena, M. (2000). Indigenous mestizos: The politics of race and culture in Cuzco, Peru, 1919-1991. Durham, NC: Duke University Press.

Economist. (2014, 22 February). Cooking up a business cluster: The Peruvian gastronomic revolution, continued. The Economist. Retrieved from http://www.economist.com/news/americas/21596956-peruvian-gastronomic-revolution-continued-cooking-up-business-cluster?fsrc $=$ rss $\mid$ ame

Fajans, J. (2012). Brazilian food: Race, class and identity in regional cuisines. London, UK: Berg.

García, M. E. (2013). The taste of conquest. Journal of Latin American and Caribbean Anthropology, 18(3), 505-524. doi:10.1111/jlca.12044

Gershon, I. (2011). Neoliberal agency. Current Anthropology, 52(4), 537555. doi:10.1086/660866

Goffman, E. (1959). The presentation of self in everyday life. Garden City, NY: Doubleday.

Leinaweaver, J. (2008). The circulation of children: Kinship, adoption, and morality in Andean Peru. Durham, NC: Duke University Press.

Mahmood, S. (2005). Politics of piety: The Islamic revival and the feminist subject. Princeton, NJ: Princeton University Press.

Martin, E. (2000). Mind-body problems. Journal of the American Ethnological Society, 27(3), 569-590. doi:10.1525/ae.2000.27.3.569

Matos Mar, J. (1984). Desborde popular y crisis del estado: El nuevo rostro del Perú en la década de 1980. Lima, Peru: Instituto de Estudios Peruanos.

Ong, A. (1999). Flexible citizenship: The cultural logics of transnationality. Durham, NC: Duke University Press.

Pastor, M. (2011, 12 Sep.). Un documento con vida propia. El Comercio, Lima, p. C1.

Pilcher, J. M. (1998). ;Que vivan los tamales!: Food and the making of Mexican identity. Albuquerque, NM: University of New Mexico Press.

Rayner, J. (2011). Chefs' manifesto: Reality check, please. Retrieved from www.guardian.co.uk/lifeandstyle/wordofmouth/2011/sep/13/ reality-check-please/print

Rousseau, S. (2012). Food media: Celebrity chefs and the politics of everyday interference. London, UK: Berg.

Ruhlman, M. (2006). The reach of a chef: Beyond the kitchen. New York, NY: Viking.

Sutton, D. E. (2014). Secrets from the Greek kitchen: Cooking, skill, and everyday life on an Aegean island. Oakland, CA: University of California Press.

Thompson, E. P. (1964). The making of the English working class. New York, NY: Pantheon. 
Weismantel, M. (2001). Cholas and pishtacos: Stories of race and sex in the Andes. Chicago, IL: University of Chicago Press.

William Reed Business Media. (2017). The World's 50 Best Restaurants 1-50. Retrieved from http://www.theworlds5obest.com/list/1-50winners

Willis, P. (1977). Learning to labor: How working class kids get working class jobs. New York, NY: Columbia University Press.
Wilson, P. J. (1973). Crab antics: The social anthropology of Englishspeaking Negro societies of the Caribbean. New Haven, CT: Yale University Press.

World Bank. (1999). Peru - education at a crossroads - challenges and opportunities for the $21^{\text {st }}$ century. Vol. 1 of Main report. Washington, D.C.: The World Bank.

Woronov, T. E. (2015). Class work: Vocational schools and China's urban youth. Stanford, CA: Stanford University Press. 